\title{
The East in the Western Perception: Orientalism in some selected Poems of Lord Byron
}

\author{
Afaf Ahmed Hasan Al-Saidi \\ Department of English \\ College of Education \\ Aden University, Republic of Yemen
}

Received: 5/20/2021

Accepted: $7 / 23 / 2021$

Published: 8/25/2021

\begin{abstract}
:
Orientalism as a literary phenomenon has been recently focused on by different writers all over the world. Many of those who write about Orientalism have not the same understanding, and the divergences are reproduced due to different attitudes toward Orientalism. From various studies concerning Orientalism, there are apparent tributaries confronting the understanding of the concept of Orientalism from different perspectives. Edward Said is one of those who, according to what many Western and Eastern writers say, represent the negative attitude towards Orientalism, and tries only to make it appear ugly and offensive. Many writers, Arabs and non-Arabs, take, more or less, the same approach Said used towards the subject of Orientalism. Others have, to some extent, tried to give excuses for the writers, especially the Romantics, for the negative impression their writings reflected on the readers when going through what is supposed to be Oriental works. Nigel Leask, Sari Makdisi, Emily Haddad, Martin Bright, Tripta Wahi and Naji Oueijan are the significant writers of this group. British orientalists did not use the right approach to look or write about the East. What irritates Said is that these orientalists did not pay attention to find any possibility by which they could bridge the gap between the European and Asiatic parts of the world. This paper tries to trace and to define Lord Byron's type of Orientalism in some of his oriental works and his chief work Don Juan.

Keywords: Don Juan, East, Lord Byron, Peppo, Romantics poetry, Orientalism, West, Western perception,

Cite as: Al-Saidi, A. A. H. (2021). The East in the Western Perception: Orientalism in some selected Poems of Lord Byron. Arab World English Journal for Translation \& Literary Studies 5 (3) 17-26. DOI: http://dx.doi.org/10.24093/awejtls/vol5no3.2
\end{abstract}




\section{Introduction}

extent, with Said's attitude concerning the negative approach the Romantics like Byron, Shelly, Landor, and Moore used to present the Middle East.

Going through Said's idea of Orientalism (1978) and the concepts related to it can be understood. The sense of hostility Said talks about clarifies. This research highlights a dispassionate approach towards Orientalism in the poetry of the nineteenth century in England, particularly some of Lord Byron. There is an agreement, to some in so many ways the reasons behind his doubts in the authenticity of the literary oriental works of the late eighteenth and nineteenth centuries; literary Orientalism is full of lies and fabrications about the Orient and particularly about Islam, Arabs and their culture. The English Romantic poets, for example, "often considered the East as a region of slavery, superstition and cruelty of monarchs oppressed all those weaknesses in mind and body" (Osborne, 1916. p.90). Writers used Orientalism as "a western style for dominating, restructuring, and having authority over the Orient" (Said, 1978. p.4). They made the Orient in general and the Middle East in particular "an idea that has a history and a tradition of thought, imagery, and vocabulary that have given it reality and presence in and for the West" (p.6). They planned to create a new Middle East with religion, history, and type of people that make the inferiority and aggressive attack in their writings reasonable.

The political and imperial interests of the writers and their culture, unfortunately, violate the knowledge presented in oriental works. Orientalists succeeded in their literary works in creating an atmosphere in which "the relationship between Occident and Orient is a relationship of power, of domination, of varying degree of a complex hegemony" (Sharfuddin, 1994. p.5). This is why the knowledge about the Orient cannot be pure. The relationship between reality and what is presented by such orientalists is suspected since they entirely depended on an assumed affinity between reality and their literary production. Thus, it is a knowledge-power relationship rather than a knowledge-reality relationship.

\section{Literature Review}

The orientalists' focus was/is on putting the differences between their race and the oriental one on the surface of their oriental writings. They turned Orientalism into "a kind of intellectual authority over the Orient in western culture" (McGuigan, 1997. p. 4). Thus, their Orientalism was directed as it was used only as a means of engaging the imperial thinking with literary production, which is a solid way to engrave imperialism, and assert the assumptions of the mental, cultural, racial, moral and intellectual inferiority of the East in the minds of the western readers.

For Said, orientalists are regarded as "products of their imperialist culture" (Sharfuddin, 1994, p.viii). The phenomenon of Orientalism, for Said, turns to be a "process of falsification [that] is precisely what made the Orient remote and seductively exotic to the Western mind," (p. xv). Orientalists, especially the Romantics, did not present the Orient in general and the Middle East in particular truthfully. They disfigured it by giving it a new frame and content that has no relation with its fundamental structure. No wonder that the image of the East, Middle East, Arabs, and Muslims was and, unfortunately, still is a typical image of an enemy by all its indications, colors, and shades. The idea "of, and Muslims was not very dissimilar from the portrayal, by the same 
cultural tools, which appeared in previous centuries, the Romantics fell into the same trap as their forbears" (Abdel-Wahed, 1992, p.61). The oriental works of Byron, Mary Shelley, Walter Scott, and all other romantics prove the truthfulness of this statement. Thus, orientalists affirm only the historical relationship "between Islam and Christianity, or East and West [that] has been essentially political" from its earliest beginning (Sharfuddin, 1994, p. xiii).

Orientalism is the most significant feature of almost Byron's literary works. The first look at his dramas and poems shows his intense clinging to the Middle East, Turkey in particular. The paper is trying to use the analytical approach to tackle the attitude of Lord Byron towards the Middle East.

\section{Discussion}

Unlike other romantic poets, Byron is privileged by having a first-hand experience of the Middle East. He spent several years in the Orient, which, as so many critics think, makes the knowledge presented in his works genuine and much more reliable than that of other writers. In 1809, Byron started a trip to the Middle East which lasted for two years. He visited Greece, Italy, Turkey, and some other countries

His literary works function as a mirror for his own life, dreams, and the difficulty he finds in merging in his society because his "deformed foot became the crucial catastrophe of his life. He saw it as a mark of satanic connection 'The lame devil"" (Lofdahl, 2005. p.18). He used to take care of his physical appearance in his youth to distract people from looking at his foot. As a young man, he was accused of committing an incest relationship with his half-sister Augusta. This incest destroyed the last part of Byron's reputation as the first part was already destroyed by the rumors of his homosexuality.

Byron's Turkish Tales were written and published during the terrible time he went through in England. The tales were written during the years of his various love affairs, which exulted his mind, and also during the rumors of his adultery, homosexuality, and incest. Some critics look at these tales and other oriental works as source from which they can get details about Byron's personal life with all its facts and rumors. Yet, Byron is considered the closest romantic orientalist to the Islamic Middle East. He spent a long time in the region; his first trip (1809-1811) and then he stayed in the area during his exile (1816-1824).

All Byron's personal, domestic and local problems from his birth till death are clearly illustrated in what is supposed to be called oriental works. The picture we can see in these works is of Byron himself, his philosophy, and his English society rather than the Middle East and its religion, customs, culture, traditions, history, and characteristics. Whenever he discusses Islam or Muslims and their life, he deliberately presents it in a distorted form since presenting reality would make the Middle East superior to him and his perverse morals.

Byron stayed in the Middle East and met Ali Pasha, the Turkish Sultan in Turkey. He saw religious rituals, like prayers, Azan, and fasting during Ramadan; he knew enough about the greatness of Muslims' life. Yet, this privilege, which was not accessible to any British orientalist, 
was not ideally and honestly used by him. His personal experience and direct dealing with the facts of the Middle East were overcome by his abnormal personality and English nature.

"He could not forget that he was a man presenting the imperial and superior Empire of England. His hatred for the English society that forced him to leave England with his scandals did not persuade him to present the reality of the Islamic Middle East." (Leask, 1992. p.71)

His nationalism made him portray the English self-image and his abnormal image as unquestionable realities of the East.

Byron's type of Orientalism is a perfect soil to help realize the meanings of all Edward Said's ideas on Orientalism. Going through some examples of Byron's way of presenting the Middle East shows that all the claims of the critics defending Byron are baseless and cannot be accurate. A close look at some of his texts shows his skill in focusing on finding or instead, creating distinctions between the West and the East. Byron's exaggeration in presenting the East and Islam must not belittled since his intentions cannot be translated in a way other than distortions.

Beppo (1818) is an excellent poem to start with tackling his Orientalism. It gives us a clear description of the steps he does when writing an oriental work. He boasts of his ability in writing oriental works:

\author{
How quickly would I print \\ A Grecian, Syrian or Assyrian tale; \\ And sell you, mix'd with Western sentimentalism, \\ Some samples of the finest Orientalism
}

(pp. 620-623)

These lines make his writing oriental texts clear for us, whether in the West or the East. He says that he can write an oriental text "quickly" since he is an unlimited source of the authenticity of knowledge about the Middle East. He does not need time to think of ideas, check the reality of what he wants to say, or consult someone before writing. As his poem was written and published when he was in exile (1816-1824), he wants to assure the readers that he became not only knowledgeable but also encyclopaedic in oriental matters.

Byron in Beppo confirms that his Orientalism is not pure. After talking about how quickly he is writing an oriental text and how he cares about the saleability of his literary production, he tells us about the content of Orientalism presented in his texts. It is "mixed with western sentimentalism." It is this type of sentimentalism that affects the reality of the Middle East and makes it more responsive to the West rather than the East as Said confirms. Byron could not or rather did not want to detach his Englishness when approaching the West. It is his western sentimentalism that makes all his oriental works replete with denotations and connotations of imperialism, colonialism, and superiority.

Arab World English Journal for Translation \& Literary Studies 
The lines in Beppo offer the main components of Byron's Orientalism. Quick writing connotes his arrogance and carelessness about whether what he writes is real or not. The process does not stop here; it goes further in a dangerous direction. His Imaginary ideas, which are supposed to be oriental, are mixed with his English sentimentalism. The process, as Byron validates, ends with not only ordinary oriental text but with "samples of the finest Orientalism."

According to Byron's accounts (1818-1824), the second step of writing an oriental text, as he explained, is to sell it. His success, as he looks at it, is confined only to get as much money as he could. He never thinks of the idea of succeeding through giving knowledge to his readers. Most of his readers of that time took what he said about the East as taken for granted. Achieving commercial success is much more important than anything else since he suffered most of his life from debts. Writing about the East is a solution, maybe the only one, to solve his financial problems.

The reality of the content of his tales and poems was not significant. He did his best to make the content of his oriental texts as a perfect source of enjoyment for the English readers who liked his way of expressing the English cultural taboos in oriental form. His texts were simply "a commodity ... to be purchased by consumers. ... Byron sought to give his fans what they wanted to purchase" (Deny, 1940. P.20). This explains the reason why, unlike Wordsworth's works, Byron's narrative tale The Corsair (1814) sold ten thousand copies on the same day it was published because it matched, as all his oriental works, the taste of the English readers (Ford, 1992). Thus, his interest in the culture of the Islamic Middle East is not pure. The priority is given to the content that satisfies the vicious taste of the readers and consequently makes his writings best sellers.

Philip Martin (1982), doubts if Byron had a genuine interest in the East. He believes that Byron made his oriental texts "a commodity for his readers, an amusement that can be detected in his deliberate indulgence ... in the verse in which he can be fairly sure that his audience will remain ignorant" (p.62). Byron and his publisher participated in creating a new trade, the trade of Orientalism in the nineteenth century. He shows no respect for the mentality of his readers by not caring for the type of knowledge they get from his distorted texts. He does not care about whether his literary content has a relationship with reality or not. His readers trust him and his knowledge presented in his texts.

In his masterpiece Don Juan (1820), Byron says "It's always best to take things upon trust" (Canto, XVI. 1. 6). He wants his readers to like him, not able to differentiate between reality and fiction as he blindly trusted Beckford's Vatheck and celebrated its correctness of custom and originality. "Only his intellectual admirers were saddened and turned away from him because of the distorted facts which he claimed to be authentic in his oriental works" (Galt, 1830. p. 155). Such English intellectual people did not accept, as the ignorant people did, to be satisfied with the imaginary erotic presentations about the Muslim Turks. Denise Millstein (1940), believes that Byron "kept pushing the limits of his audiences' acceptance ... becoming increasingly villainous and simultaneously feminized" (p.6). What he mainly did is that, instead of pushing them to follow manly values and virtues, he persuaded them to enjoy what is feminine. 
Byron's intention to make the Middle East the centre of his masterpiece is mentioned clearly in the first canto. He illustrates his opinion about a fundamental world issue as it was seen at that time. All the romantic poets, in one way or another, showed their admiration for the Egyptian civilization and its relics. For merely being different, Byron expresses his degradation of the world's most ancient civilization that puzzled all the nations. He says:

\section{What are the hopes of Man's Old Egypt's King? \\ Cheops erected the first Pyramid, And largest, thinking it was just the thing \\ To keep his memory whole, and mummy hid: \\ But somebody or other rummaging, \\ Burglaviously broke his coffin's lid. \\ Let not a monument gives you or me hopes, \\ Since not a pinch of dust remains of Cheops. \\ All things that have been born, \\ Were born to die. Canto I.11.153-162}

He is making fun of the Egyptian civilization that attracted the whole world and still does. The whole world saw and still see the Pyramids as a symbol of beauty, genius and eternity which intellectuals like Wordsworth wished for Man's knowledge and achievements. For Byron, the largest Pyramid is just a "thing." His shallow mentality and limited thinking prevent him from going deeper and looking at this monument as a practical proof of showing Man's ability and skill in immortalizing himself. The Pyramids and the mummies give hope to some other western intellectuals. Byron is different; the existence of mummies after thousands of years is not a subject that deserves attention. Those Pyramids and mummies failed in raising any sexual ideas or interests in Byron's mind; they are trivial. He looks at them as easy targets for burglars who look for treasure. These figures cannot give hope for any kind, neither for him nor for his readers. Mummies are simply remained a pinch of dust. He even tries to make the readers doubt about the benefit the King of Egypt got by building the Pyramids.

Byron's reaction towards the Egyptian Pyramids and Mummies is normal if seen from a certain angle. The Pyramids are an eternal sign of the superiority of the Middle East. They are strong evidence of the power and uniqueness of one of the civilizations of the East. For an imperialist like Byron, they would appear as an irritating actual practical proof of the imperialism of the East, which is totally rejected. Such monuments with their connotations, content knowledge engraved inside them, and historical background would be a source of doubts for the English about their position in the world.

In his masterpiece, Don Juan, Byron's hero, Juan, is a Spanish male, who has many problems at home. Juan is described as sixteen-year-old, tall, handsome, and slender. Certainly, his hero cannot be lame as he is; he is a perfect example of a man regarding his physical appearance and sexual attractiveness. In the same canto, Byron shocks his readers by showing a lovemaking scene. The performers of this scene are Juan and Dona Julia who is older and more experienced than he 
is. It is this half-Moorish lady who initiates the relation by making straightforward sexual advances seducing him. Juan's first sexual experience in his life is with a half-Arab Muslim lady.

For him, it is the East and its loose manners that make it possible for him to have sex at an early age. In canto V, Juan is displayed in the Turkish slave market. Then he is brought to the wing of the Harem in the palace of the Muslim Sultan.

Byron's hero in so many different situations face a sense of difficulty in a particular country, then he meets a lady of high rank who almost begs him to have sex with her. Byron's hero has a magical effect on powerful Muslim ladies. Byron's imagination gives the Muslim woman a very restricted assortment to show herself. A Muslim lady is either a Sultana, as in Don Juan, who is not content with her life and husband, a Pasha's daughter who is willing to elope with her lover (just like what happens in his country) as in Bride of Abydos or a caged lady who belongs to Harem. This is a "straightforward confrontation of English prejudice against the Islamic status of women " (Sharfuddin, 1994. p.244). Because of Byron's imperial thinking, the image of Muslim women has to be distorted in the minds of both western writers and readers. All his readers have depended on the claimed authority of his oriental expertise while being in the Middle East. Peter Cochran (2006) strongly believes that Byron's Orientalism "has been insufficiently examined because it was based on experience... [his ideas] ... also derived much of his knowledge of the Orient from books which he used more as factual sources" (p.3).

Because Byron is mainly an imperialist, he makes his readers see the Islamic Middle East as an example of imperialism to irritate the West. For them, the East is forever weak and inferior; it is not qualified to be imperial. The Harem is one of the imperial faces of Turkey. Showing Muslim ladies as prisoners in a closed room waiting for their man to have fun with them, shows the extent of the brutality of the Turks. Byron's readers admire the Byronic hero when he challenges Turkish imperialism and has a love affair with a Muslim lady. Byron has his own method "of structuring his analysis of colonial relations through stories of cross-cultural love in which the woman suffers" (Fulford, 1998. p.36).

In Don Juan, the hero challenges Turkish imperialism and shows his sexual conquest; he is in the most sacred place of the Turkish palace -the Harem- and is forced to have sex with the Sultana. In The Corsair, Conrad is the Western hero who liberates Gulnar from the prison of her marriage. Because of Gulnar's love for him, she kills the Pasha, her Muslim husband and turns back on her religion -Islam- for the sake of her Western lover.

Byron accomplished his imperial duty by stressing the inferiority of the Middle East. All the Islamic or Turkish aspects presented in his works are meant to bring the superiority of the West to the surface. He shows the region as "inferior that is actually backward, peculiar, and unchanging, depicted in dominating and sexual terms" (Sered, 2005. p.2). All his western heroes are morally, culturally, and virtually superior to all Muslim characters of his works. Because of Juan's virtues, the Sultana turns to be weak in front of him.

John Galt, who went with Byron to the Middle East, believes that all Byron's descriptions in Don Juan are not valid. He says that the images of the Sultan, the Sultana, and the Harem are 
"more indebted to the author's fancy than any of those other bright reflections of realities " (Galt, 1830. p. 85). Galt affirms that Byron did not depend on knowledge of real things; he wrote from imaginary circumstances and fancied both situations and feelings which had no reference to his own, nor to his experience. Abdel-Wahed (1992), says that behind those fabricated themes and provocative representations of the ignorant and inferior Middle East, "Byron's message is that the Middle East is morally weak while the West gains its pride from its strongly built values and principles " (p. 140).

Byron uses the unique type of imperialism of his time in his writings. It employs attacks on the imperial, tyrant, corrupt and cruel regime to justify its later conquest. Tim Fulford (1998) believes that Byron's Eastern Tales, "the age's most popular imperial fiction, were founded on the sentimental depiction" (p.37).

Byron, as Edward Said believes about all the romantics, serves only political ends in his oriental texts. Unlike Wordsworth, Byron exploited his Orientalism to enhance his country's politics. The English Empire of the nineteenth century looked at the Islamic Middle East as a perfect place to show its imperialism, dreams of colonialism and superiority. He "accepted the basic distinction between East and West as the starting point to elaborating whatever is related to the East " (Jones, 1999. p.8).

Byron's idea about the Napoleonic wars explains his political thinking. He considered those bloody wars glorious. He supported Napoleon's invasions in Europe, and the Islamic Middle East. He regarded the character of Napoleon as "a defender of liberty, and this entailed supporting his dreams to establish an Empire over Egypt" (Abdel-Wahed, 1992. p.133). The position of his Christian western culture as the world's dominant colonial power was fixed in his mind. His complicity in showing that power as an orientalist was highly celebrated. All his oriental works show the British dream of the collapse of the Ottoman Empire that is presented as full of decadence, corruption, and cruelty.

Leila in The Giaour admires the morality and superiority of Giaour and that is why she surrenders to his sexual desires forgetting her husband and religion. It is the kindness and the human treatment of Conrad that makes Gulnar kill her husband in The Corsair. Conrad's gentle behaviour is out of his superior religion-Christianity. So Gulnar confidently turns back on Islam and becomes a Christian. All his works "reflect a supercilious attitude covered with arrogance; they suggest a feeling of supremacy and superiority towards the Middle East " (p.63). All Muslims who are inferior must discover the greatness of Byron's heroes.

Byron's way of dealing with the Middle East shows his deep-rooted racism. He proves, as Said believes, that the nineteenth-century culture "was racist with a greater or lesser virulence depending on the individual " (Said, 1978. P.66). Byron's racism prevented him from showing the Middle East or Islam as superior or perfect even once in his works. All the ill qualities and characteristics belong to the Middle East, while generosity, nobleness, bravery, thoughtfulness, honour, dignity, and morality always come from the West. This makes us recall Said's statement that "the web of racism, cultural stereotypes, and political imperialism ... dehumanizing ideology 
in the Arab or Muslims is very strong indeed " (P.27). Byron is charged with distorting the image of the Middle East. Because the content of his oriental works is merely a self-image for him and his country, his Orientalism cannot be realistic. The Middle East presented in his texts is distorted though he knew its reality quite well. All his fantasies and sexual deviated ideas are presented, affirming the validity of the region. His type of Orientalism proves the authenticity of Said's assertion that "the real Orient is not only ignored or avoided by orientalists: it is not even perceived by them " (Sharfuddin, 1994, p. xvi).

\section{Conclusion}

His oriental works, including Don Juan, show how they are perfect examples of Literature of power. They simply present Byron's effort in serving his country's political and imperial interests by means of showing the Middle East as a weak, inferior, immoral, corrupt, and irreligious region which is in need to be conquered by his country to be reformed. The degrading and terrible image he describes is a pure image of the self rather than of the other. Yet, the self-image he gives is misleading, since he does his best to turn it into a real image of the other, leaving no chance to his readers to recognize this fact. Thus, the image of the Middle east presented in his oriental works is a distorted picture of realitya picture that shows his malice and imperial mentality. He believes in distinction, racism, false superiority, at the expense of inferiorzing the other, conquest, falsehood in description and in supporting blindly the literary fashion of distorting the region. He uses his imagination to create and stress the essential fabricated inferiority of the Middle East.

He detaches himself neither from his Englishness nor from his immoral personality. Failure of marriage, adultery, incest, and sodomy become the content of his oriental poems, but in reality, these concepts are the reflection of the scandals of his own life. The mask he uses to deceive critics about his pure interests in the region has been taken off, and therefore, Byron fails in presenting a pure interest when approaching the Middle East. Byron is proved to be the typical representative of those Romantics, showing the negative type of Orientalism.

\section{About the Author: \\ Dr. Afaf Ahmed Hasan Al-Saidi. Associate professor of English Language and Literature in the Department of English. College of Education, Aden University. Yemen. Head, English Department (October 2002- April 2005). College of Education, Aden University. Head, English Department (March 2008- March 2010). College of Education, Aden University. B.A. English Department, College of Education. Aden University, Yemen, 1990. M.A. English Department, College of Education. Aden University. (Higher Education Link with Hyderabad University-India.1993). Ph.D. Department of English Language and Literature, College of Arts. Cairo University,2001. Currently, an associate professor of English Language and Literature at King Khalid University. Abha, K.S.A.}

\section{References}

Abdel-Wahed, S. (1992). Orientalism and Romanticism: A Historical Dialectical Relationship, (Unpublished Ph.D. Dissertation). Duquesne University, Pennsylvania-School of Graduate Studies.

Cooke, M. (1979). Acts of Inclusion: Studies Bearing on an Elementary Theory of Romanticism. London: Yale University Press. 
Cochran, P. ed. (2006). Byron and Orientalism. Cambridge: Cambridge Scholars Press. www.c-s-p.org/Flyers/9781904303909.pdf $>25^{\text {th }} / 07 / 2021$

Deny, W. (2008). Shelley. London: T.C. \& E. C. Jack. Universal Digital Library. Available at http:// www. Archiver/ stream/ Shelley wate_djvr.txt $19^{\text {th }} 7 / 2021$.

Ford, B. (1992). The Roman Age in Britain. Cambridge: Cambridge University Press.

Fulford, T. (1998). Romanticism and Colonialism: Writing and Empire 1780-1830. Cambridge University Press.

Galt, J. (2003). The Life of Lord Byron. London: Arnold. http://www.gutenberg.org/etext/10421 $25^{\text {th }} / 7 / 2021$.

Jones, D (1999). Edward Said's Orientalism revisited. The New Criterion. http://www.newcriterion.com/archive/17/jan99/saidhtm. $25^{\text {th }} / 7 / 2021$.

Leaks, N. (1992). British Romantic Writers and the East: Anxieties of Empire. Cambridge: Cambridge University Press.

Lofdahl, W. (2005). Androgyny: Byron's Role in Romantic Sexual Counter Culture. (Unpublished Master's thesis). Florida State University. USA

Martin, P. (1982). A poet before his Public. Cambridge: Cambridge University Press.

McGuigan, J. (1997). Orientalism: Studies in Culture. An Introductory Reader. London: University of Calgary. Cultural Studies in Communication, 22.p.4

Osborne, A. (1916). Oriental Diction and Theme in English Verse, 1740-1840. Kansas: Kansas University Press.

Oueijan, N. (1916). Oriental Diction and the Themes in English Verse, 1740-1840. Kansas: Kansas University Press.

Said, E. (1978). Orientalism. New York: Vintage Books.

Sered, D. (2005). On Edward Said's Orientalism. Emory University. Postcolonial Studies. Electronic Articles Centre. http://www.emory.edu/bahri/orientalism.html. 25th /7/2021.

Sharfuddin, M. (1994). Islam and Romantic Orientalism: Literary Encounter with the Orient. London $\&$ New York: I. B. Tauris and Company Publishers. 